ECONOMICS

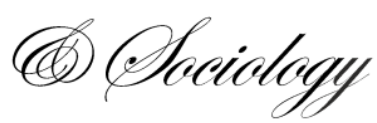

Halaskova, M., Gavurova, B., \& Korony, S. (2020). Change of EU28 countries research and development indicators between 2010 and 2015. Economics and Sociology, 13(1), 230-248. doi:10.14254/2071-789X.2020/13-1/15

\title{
CHANGE OF EU28 COUNTRIES RESEARCH AND DEVELOPMENT INDICATORS BETWEEN 2010 AND
} \section{5}

\author{
Martina Halaskova \\ VŠs- Technical University of \\ Ostrava, Faculty of Economics, \\ Ostrava, Crech Republic \\ E-mail: martina.halaskova@,vsb.cz.

\section{Beata Gavurova} \\ Tomas Bata University in Zlin, \\ Crech Republic; Faculty of \\ Management and Economics, Zlin, \\ Czech Republic \\ E-mail:gavurova@,utb.cz

\section{Samuel Korony \\ Matej Bel University, Faculty of Economics, Banská Bystrica, Slovakia \\ E-mail: samuel.korony@,umb.sk}

Received: May, 2019

1st Revision: November, 2019

Accepted: February, 2020

DOI: $10.14254 / 2071-$

789X.2020/13-1/15

JEL Classification: C61, 032, R11, R12

\begin{abstract}
In the paper evaluation of research and development efficiency change in EU28 countries between 2010 and 2015. The authors used the non-radial and nonoriented Malmquist index of available R\&D indicators of EU28 countries (five inputs and two outputs) and have found six groups of EU28 countries from the viewpoint of three index terms values (efficiency shift, frontier shift and Malmquist index). The relatively best group of countries with progress in both efficiency shift and frontier shift terms (Malmquist index $>1$ ) is represented by two countries: Italy and Germany. The last group contains the six relatively worst countries with regress in all three terms (efficiency shift, frontier shift and Malmquist index $<1$ ): Netherlands, Greece, Malta, Poland, Luxembourg and Portugal. It was found by means of the nonparametric test that post-socialist countries are not different from capitalist EU countries from the viewpoint of efficiency change between 2010 and 2015. The biggest change in R\&D efficiency using the Malmquist index between 2010 and 2015 was found in Spain, Latvia, Denmark and Ireland. Conversely, the smallest change in R\&D efficiency is demonstrated by Poland, Luxembourg and Portugal.
\end{abstract}

Keywords: research, development, Malmquist indices, data envelopment analysis

\section{Introduction}

R\&D policy is a standard part of an integrated system of national policies related to main social fields in most developed countries (Kiselakova et al., 2018). Research and development (R\&D) and innovation are a central area of individual national and international policies and innovative strategy (Ivanová \& Čepel, 2018; Hei Cheung et al., 2019; Ř́hová et al., 2019). First and foremost, this concerns the connection of R\&D policies with education, innovation, employment, information and business policy (Moed et al., 2005; Hackett et al, 2008; Backer, 2015; Bilan et al., 2019; Stepanova et al., 2019; Dvorský et al., 2019). 
Research and development play a key role in generating new knowledge, products and technological processes, which are a necessary condition for stable, sustainable social growth. From the viewpoint of macro-economy, the areas of research and development belong to the category of intensive (qualitative) sources of economic growth, i.e. they enable the increase in and improvement of the productivity based on the factors of production (European Commission, 2016). Significant economic indicators, such as economic growth, migration and unemployment rate, or company competitiveness, are dependent, to a marked extent, upon the outcomes of research and development. In connection with competitiveness and research potential, it is also necessary to take into account factors that influence the assessment of their sustainability (Drastichová, 2015; Mishchuk \& Grishnova, 2015).

The level and intensity of research, development and innovations are connected with the economic level of a respective country, the dynamic of economic development and the structure of creating added value and employment. Currently, what mainly dominates the development of economies and societies is knowledge connected with research and development outputs. Some older but also newer researchers already evaluated change R\&D efficiency and productivity R\&D growth when used Malmquist index e.g. Dai and Liu (2009); Thomas et al.(2009); Lu and Liu (2010); Jang et al. (2016) or Han et al.(2016).

The objective of the paper is the analysis and evaluation of R\&D efficiency change in EU28 countries between 2010 and 2015. The main analytical method is Data Envelopment Analysis (DEA) and its Malmquist indices. We wanted to set a mirror to EU28 countries in the field of R\&D efficiency and possibly to make suggestions for improvement for the least efficient countries. In connection with the objective, two research questions are verified in the article: 1) We supposed that R\&D efficiency is influenced by financial structure potential that is countries with larger financial potential and larger share of business sector are more efficient than countries with a prevailing share of public sector in R\&D. 2) Research question whether post-socialist (transition) countries have got smaller efficiencies in comparison with original EU15 countries was also tested.

\section{Theoretical background and literature review}

Research and innovation are keys to building a prosperous future for the EU. Purpose European Research Area (ERA) is to increase the competitiveness of European research institutions by bringing them together and encouraging a more inclusive way of work, increased mobility of knowledge workers and deepened multilateral cooperation among research institutions among the member states of the European Union are central goals of the ERA (European Commission, 2018). They, therefore, figure prominently in the Europe 2020 strategy and the European Semester process and underpin progress boost to jobs, growth and investment, to developing the digital single market and developing the Energy Union (Staničková, 2017).To implement the strategy Europe 2020 in the field of R\&D, areas to focus on are better conditions for financing research, development and innovations, where financial capabilities of EU countries are an important prerequisite (Dul’ová Spišáková et al., 2017).

\section{1. $R \& D$ efficiency and productivity}

Hawdon (2003) the definition of efficiency is divided into three features: technical, economic and allocative efficiency. Melecký and Staničková (2012) analyze the degree of efficiency achieved in European countries which are perceived as a reflection of the level of competitive potential in the years 2000 and 2010. Evaluation and measurement of R\&D 
efficiency and productivity by used Data Envelopment Analysis and Malmquist index are addressed in the publications of many authors. Dai and Liu (2009) evaluate R\&D efficiency and productivity growth of 16 High-Tech industries in China over the period 2002 to 2007 by using Data Envelopment Analysis (DEA) as a non-parametric method and used Malmquist index to examine technical efficiency change decomposed into pure technical efficiency change and scale efficiency change, technical change and total factor productivity (TFP) change for these High-Tech industries. Thomas, Jain and Sharma (2009) investigate R\&D efficiency in 22 countries, 20 of the members of the OECD, and the Russian Federation and China. The analysis is carried out using the Malmquist Productivity Index for the periods 2002-2004 and 2004-2006. Lu and Liu (2010) employ the Malmquist index, to decompose productivity growth into technical efficiency and technological change. The results indicate that the increase in $R \& D$ productivity is mainly attributed to the increase in technical change, and the efficiency gain found is largely the result of improvements in scale efficiency. Park (2015) analyzes the efficiency and productivity change within government subsidy recipients of a national technology innovation research and development (R\&D) program. Data envelopment analysis is adapted to measure the efficiency and productivity change, which is measured in the Malmquist index. Jang, Lee and Suh (2016) measure the cumulative change in research and development $(R \& D)$ efficiency of globally leading $R \& D$ companies in the technology industry by use Data Envelopment Analysis/Malmquist index to analyse 49 such companies. Results indicate that the overall R\&D efficiency of these globally leading $R \& D$ companies declined slightly during the period 2007-2013.

Han, Asmild and Kunc (2016) examine the R\&D efficiency employ data envelopment analysis and to identify the regions' R\&D performances relative to the best practices from the static perspective, and the Malmquist productivity index to evaluate their changes in performance. Other authors e.g. Laliene and Sakalas (2014) define the concepts of R\&D productivity, $R \& D$ efficiency and $R \& D$ effectiveness. The authors provide an analysis of existing R\&D assessment structures or models as well as identify its advantages and disadvantages. Ekinci and Karadayi (2017) analyse and summarize the studies on R\&D efficiencies of countries, list the commonly used indicators for the analysis and compare the efficiencies of all of the 27 European Union countries with respect to their R\&D activities in order to measure the relative efficiency scores by used Data Envelopment Analysis (DEA).Halásková and Bazsová (2016) evaluated efficiency research activities based on selected indicators of research and development in 28 European Union countries using the method of DEA in the year 2013 compared to the year 2012. The research focuses closely on indicators of human resources and R\&D intensity.Wang and Huang (2007) analyze R\&D efficiency in 30 OECD and non-OECD countries also taking into account environmental factors such as knowledge of the English language. They find that a large portion of the inefficiency can be explained by a country's English proficiency indicator. Lee and Park (2005) have performed a CRS DEA study on 27 countries and have concluded that Asian countries, in general, are inefficient in R\&D. Also, Sharma and Thomas (2008) used DEA to assess the R\&D efficiency of various countries e.g. developed countries, developed countries from Western Europe or some non-European countries. Other authors Guan et al. (2016) solve the influence of collaboration network structure on national research and development (R\&D) efficiency. Based on the collections of R\&D data for each country authors measured R\&D efficiency scores by using the Malmquist productivity index associated with data envelopment analysis. Li and Wang (2017) evaluate on R\&D input-output performance of the major sectors of industrial enterprises based on the DEA method and analyze the input-output performance of R\&D activities of the major sectors of industrial enterprises in Hebei 
Province, and then the major problems of low efficiency of input-output performance of $R \& D$ activities.

\subsection{Innovative performance and indicators of $R \& D$}

Innovative performance and innovation policy are closely linked to the evaluation and efficiency of R\&D. European Commission (2016) presents an in-depth indicator-based analysis of the EU's science, research and innovation performance and provides insight into the underpinning factors and drivers. It provides extensive evidence of the EU's performance in relation to each of these three challenges. Braczyk, Cooke and Heidenreich (2004) define innovative environment as features which generate knowledge (universities, research institutes) on the one hand and sub-systems of knowledge (companies) on the other, for the sake of commercial application of new information. As Rodríguez-Pose and Crescenzi (2008); Žítek et al. (2016); Machová et al. (2017); Mishchuk et al. (2019); Prokop \& Karbowski (2018) argue, the ability of the countries to make effective use of their internal resources and respond flexibly to external development stimuli in the given conditions is one way of manifesting the innovation potential. According to other authors, Cowan and Van de Paal (2000); Freeman (1995); Borrás and Edquist (2013), innovation policy blends with scientific and research policy and its main role is to embrace not only research and development itself, but mainly the complex innovation system (the education system, the labour market, the social system, the financial system determining access to R\&D funding and innovation).

Albu (2011) and Dobrzanski (2018) on focus is mainly the aspect in connection with the allocated total R\&D expenditure (GERD), as one of the Europe 2020 targets and the evaluation of R\&D efficiency. Analyses of total expenditures as \% of GDP (GERD) and their efficiency in EU countries examine also Bojnec and Ferto (2014); Corea (2014). Other authors solve mutual dependence between total expenditures on the R\&D and other key indicators R\&D e.g. economic growth, patents, scientific publications in the EU countries (Ravselj, Aristovnik, 2018; Szarowska, 2017). Another indicator which shows a higher orientation on innovation and competitive production with a high added value is the number of patents applied by the subjects of the given economy. Jaumotte and Pain (2005) evaluate the efficiency of R\&D and patents activities. The orientation on a knowledge- and the innovation-based economy is, to a marked extent, also determined by the number of publications and cited publications (SJR, 2017). Moed et al. (2005) and van Raan et al. (2009) evaluate scientific publications, analysis of citable publications and the quality of published results. Prokop and Stejskal (2017) solve innovation performance in EU countries in 2015 with a focus on the individual categories of innovators (Innovation Leaders, Strong Innovators, Moderate Innovators, Modest Innovators). Authors performed a microeconomic analysis of the situation in these countries' firms to analyse the conditions of their innovation environment and uncover barriers to their innovation activities. Nasierowski and Arcelus (2012) compare results of the assessment of technical efficiency of innovativeness for 2005 and 2010. In this research are presented Critical comments regarding the Innovation Union Scoreboard (IUS) approach, along with recommended modifications. 


\section{Methodology and data}

\subsection{Methods}

In our paper, we used both classic Pearson correlation coefficients and robust Spearman coefficients and Malmquist index analysis. Then the result of DEA analysis is a table with 28 efficiencies. Besides descriptive statistics, we used non-radial and non-oriented Malmquist index (Cooper et al., 2007). The objective of our non-radial and non-oriented DEA model is to optimise both inputs and outputs simultaneously. DEA is a non-parametric approach for frontier estimation. Basic models are discussed in the works of many authors, and they are applied in many areas. In DEA analysis there are two basic approaches in this case. One approach is to pool the data and estimate one single efficient frontier. Then we obtain efficiency estimates for each DMU relatively against the same frontier, and then trends in efficiency estimates of individual producers may be of interest (Fried, et al., 2008; Sherman and Zhu, 2006; Tone, 2002). The second one uses sets of single periods for efficiency estimates (window analysis and Malmquist indices). Here we mention briefly the principle of dynamic DEA analysis based on Malmquist indices. The Malmquist index evaluates the productivity change of a DMU (decision-making unit) between two time periods and is an example in "comparative statics" analysis (Cooper et al., 2007). It is defined as the product of efficiency-shift and frontier-shift terms. The efficiency-shift term relates to the degree to which a DMU changes (improves or worsens) its efficiency relative to the efficient frontier. It is the change in relative efficiency. The frontier-shift (or innovation) term reflects the change in the efficient frontiers (production frontiers) between the two time periods. The Malmquist total factor productivity is then simply computed by the product of efficiency shift and frontier shift. Interpretation of all three terms is simple and similar to common indices: value $>1$ indicates progress, value $=1$ and value $<1$ respectively indicate no change (stagnation) and regress.

Malmquist index is the geometric mean of the two efficiency ratios: the one being the efficiency change measured by the period 1 technology and the other the efficiency change measured by the period 2 technology.

$$
M I=\left[\frac{\delta^{1}\left(\left(x_{o}, y_{o}\right)^{2}\right)}{\delta^{1}\left(\left(x_{o}, y_{o}\right)^{1}\right)} * \frac{\delta^{2}\left(\left(x_{o}, y_{o}\right)^{2}\right)}{\delta^{2}\left(\left(x_{o}, y_{o}\right)^{1}\right)}\right]
$$

It consists of four terms: $\delta^{1}\left(\left(x_{o}, y_{o}\right)^{1}\right), \delta^{2}\left(\left(x_{o}, y_{o}\right)^{2}\right), \delta^{1}\left(\left(x_{o}, y_{o}\right)^{2}\right)$ and $\delta^{2}\left(\left(x_{o}, y_{o}\right)^{1}\right)$. The first two terms are related to the measurements within the same time period, while the last two are for intertemporal comparison.

Malmquist non-radial and non-oriented model deals with input and output slacks. So called slack based model is used for computing $\delta^{\mathrm{t}}\left(x_{o}, y_{o}\right)$ by the following fractional program:

$$
\delta^{t}\left(x_{o}, y_{o}\right)=\min _{\lambda, s^{-}, s^{+}}\left(1-\frac{1}{m} \sum_{i=1}^{m} \frac{s_{i}^{-}}{x_{i o}^{s}}\right) /\left(1+\frac{1}{q} \sum_{i=1}^{q} \frac{s_{i}^{+}}{y_{i o}^{s}}\right)
$$

subject to

$$
\begin{aligned}
& x_{o}^{s}=X^{t} \lambda+s^{-} \\
& y_{o}^{s}=Y^{t} \lambda-s^{+} \\
& L \leq e \lambda \leq U \\
& \lambda, s^{-}, s^{+} \geq 0 .
\end{aligned}
$$

In the nextpart, we present briefly statistical parameters of analysed variables. 


\subsection{Data}

Our research objects are R\&D indicators of EU28 countries. Data for the year 2010 and 2015 are available at Eurostat (Statistic database - Research and Development) and Scopus database (Scimago Journal \& Country Rank). In all reports we use common abbreviations of EU28 countries with corresponding year (Austria - AT , Belgium - BE, Bulgaria - BG, Croatia - HR, Cyprus - CY, Czech Republic - CZ, Denmark - DK, Estonia EE, Finland - FI, France - FR , Germany-DE, Greece-EL, Hungary-HU, Ireland-IE, Italy-IT, Latvia-LV, Lithuania - LT, Luxembourg - LU, Malta - MT, Netherlands - NL, Poland - PL, Portugal - PT, Romania - RO, Slovakia - SK, Slovenia - SI, Spain - ES, Sweden - SE and United Kingdom - UK) (for instance MT10 is abbreviation of Malta in the year 2010). We analysed available indicators of R\&D during two periods 2010 and 2015 . For the sake of the assessment, 2010 was chosen as the first year of the application of the Europe 2020 strategy in research and development and 2015 as the half of the strategy period.As input indicators were used $R \& D$ expenditure by the government sector (GOVERD), R\&D expenditure by higher education sector (HERD) and R\&D expenditure by business enterprise sector - BERD (all as \% of GDP), total researchers (FTE), human resources in science and technology (HRST, \% of active population in the age group 25-64) and employment in total service intensive sectors (\% of total employment). Output indicators are the number of scientific publications and high-tech export (\% of total export). Characteristics of input and output indicators are in Table 1.

We consider $R \& D$ production process as a special type of production function $(Y=f$ $(\mathrm{K}, \mathrm{L}))$ where expenditures are capital inputs and researchers (FTE), HRST and employment in total service intensive sectors are human labour inputs. Two values of total researchers (FTE) were missing (France in 2015 and Greece in 2010). Corresponding values were estimated by the linear regression model. The quality of published results can be evaluated by the level of the journals and citing rate (SJR, 2017). In our analyses, we used only the number of scientific publications for two reasons. The number of citable publications is tightly correlated with the number of publications. And in addition, the number of citable publications in 2015 is not definite at all and it will grow further in the coming years. The patent indicator was not included in our analysis. Disadvantage the number of patents (from EPO) is its late availability in comparison with other R\&D indicators and for some countries patent indicator values are only estimates. We wanted to involve all $R \& D$ relevant indicators and at the same time to obtain reliable and meaningful efficiency estimates for EU28 countries. We have got R\&D data of EU28 from two different periods - 2010 and 2015. In Table 2 we present basic statistic parameters (Mean $=$ arithmetic mean, Std. dev $=$ standard deviation) of our EU28 R\&D indicators - researchers (FTE) and a number of scientific publications are in thousands. 
Table 1. Input and output indicators

Input indicators
R\&D expenditure in the
of GDP (GOVERD)
R\&D expenditure in the
higher education sector
(HERD)

R\&D expenditure in the higher education sector (HERD)

Characteristics
Government expenditure on R\&D (GOVERD) represents the
component of GERD incurred by units belonging to the government
sector. It is the measure of expenditures on intramural R\&D within the Government sector during a specific reference period.

Higher education expenditure on R\&D (HERD) represents the component of GERD incurred by units belonging to the Higher education sector (all universities, colleges of technology and other institutions providing formal tertiary education programmes). It is the measure of intramural $R \& D$ expenditures within the Higher education sector during a specific period.
R\&D expenditure in the business enterprise sector as \% of GDP (BERD)

Business enterprise expenditure on R\&D (BERD) represents the component of GERD incurred by units belonging to the Business enterprise sector (all resident corporations, including not only legally incorporated enterprises and all other types of quasi-corporations, i.e. units capable of generating a profit or other financial gain for their owners).

It is the measure of intramural $R \& D$ expenditures within the Business enterprise sector during a specific reference period.

Total researchers (FTE) Researchers are professionals engaged in the conception or creation in thousands of new knowledge, products, processes, methods and systems, and in
Source

Eurostat

Eurostat

Eurostat

Eurostat the management of the projects concerned. FTE (Full-time equivalent) corresponds to one year's work by one person (for example, a person who devotes $40 \%$ of his time to R\&D is counted as 0.4 FTE.

\begin{tabular}{lll}
\hline $\begin{array}{l}\text { Human resources in } \\
\text { science and technology } \\
\text { (HRST) \% of the active }\end{array}$ & $\begin{array}{l}\text { The active population in the age group 25-64 that is classified as } \\
\text { HRST (i.e. having successfully completed an education at the third } \\
\text { population }\end{array}$ & $\begin{array}{l}\text { Eor or being employed in science and technology) as a percentage } \\
\text { of the total active population aged 25-64. }\end{array}$ \\
\hline $\begin{array}{l}\text { Employment in total } \\
\text { service intensive sectors }\end{array}$ & $\begin{array}{l}\text { Employment in high- and medium-high technology manufacturing } \\
\text { sectors and knowledge-intensive service sectors (KIS) is a share of }\end{array}$ \\
& $\begin{array}{l}\text { employment in high- and medium-high technology manufacturing } \\
\text { sectors and in knowledge-intensive service sectors of total } \\
\text { employment. }\end{array}$
\end{tabular}

\begin{tabular}{llc}
\hline Output indicators & \multicolumn{1}{c}{ Characteristics } \\
\hline $\begin{array}{l}\text { Number of scientific } \\
\text { publications (in } \\
\text { thousands) }\end{array}$ & $\begin{array}{l}\text { Scientific publications include reviewed paper, book, chapter in a } \\
\text { scientific book and article in proceedings. }\end{array}$ & Scimago \\
\hline $\begin{array}{l}\text { High-tech export (\% of } \\
\text { total export). }\end{array}$ & $\begin{array}{l}\text { High technology products are defined according to SITC Rev.4 as } \\
\text { the sum of the following products: Aerospace, Computers-office } \\
\text { machines, Chemistry, Non-electrical machinery, Armament) }\end{array}$ & Eurostat \\
\hline
\end{tabular}

Source: Authors according to Eurostat (2017) and SJR (2017). 
Table 2. Statistic parameters of EU28 R\&D indicators

\begin{tabular}{lccccccc}
\hline Indicator & Mean & Median & Std. dev. & Min & Country & Max & Country \\
\hline $\begin{array}{l}\text { Expenditure on the government } \\
\text { sector (GOVERD) }\end{array}$ & 0.20 & 0.18 & 0.095 & 0.02 & MT10 & 0.41 & DE15 \\
\hline $\begin{array}{l}\text { Expenditure on the higher } \\
\text { education sector (HERD) }\end{array}$ & 0.41 & 0.38 & 0.225 & 0.05 & BG15 & 0.99 & DK15 \\
\hline $\begin{array}{l}\text { Expenditure on the Business sector } \\
\text { (BERD) }\end{array}$ & 0.93 & 0.74 & 0.675 & 0.08 & CY10 & 2.59 & FI10 \\
\hline Total researchers (FTE) & 61.620 & 31.968 & 89.5930 & 0.587 & MT10 & 387.982 & DE15 \\
\hline HRST & 42.63 & 42.70 & 8.688 & 23.9 & PT10 & 58.8 & LU15 \\
\hline Employment in KIS & 38.49 & 35.90 & 7.662 & 19.8 & RO10 & 55.2 & LU10 \\
\hline High-tech exports & 12.24 & 10.15 & 7.054 & 3.0 & PT10 & 32.9 & MT10 \\
\hline Scientific publications & 34.347 & 16.397 & 47.0449 & 0.323 & MT10 & 188.882 & UK15 \\
\hline
\end{tabular}

Source: Authors calculation according to Eurostat (2017) and SJR (2017)

In our results in table 2 show that standard deviation is relatively large in comparison with mean in the case of researchers (FTE) and in case of a number of scientific publications. It indicates possible skewed distributions of indicators or the presence of outliers. Malta in 2010 appears in three indicators from the viewpoint of minimum values. It is understandable because of its relatively small size. But Portugal in 2010 also has got minimum values in two indicators. Maximum values are divided more equally among countries (Germany in 2015 two indicators).In table 3 are robust Spearman correlation coefficients among inputs and outputs. Critical values of Spearman correlation coefficients are $0.264(\mathrm{p}<0.05), 0.343(\mathrm{p}<$ $0.01)$ and $0.432(\mathrm{p}<0.001)$ (Sachs, 1984). We expected positive correlations between inputs and outputs. We can see that expenditure by the government sector is not significantly correlated with any of outputs. That is why we excluded R\&D expenditure by the government sector from further analyses. High-tech exports are significantly correlated with human resources in science and technology (HRST) and with employment in total knowledgeintensive service sectors (KIS) $(\mathrm{p}<0.001)$. The second output the number of scientific publications is positively correlated with expenditure in the higher education sector, with expenditure in the business sector and with researchers FTE ( $<<0.001)$. Indicators of human resources in science and technology do not correlate with a number of scientific publications. We think that cause of it is in the type of analysed indicators. Indicator HRST is relative (in $\%$ ). It is also the case of employment in total knowledge-intensive service sectors (KIS). But a number of scientific publications is an absolute indicator. So it is understandable that it does not correlate with indicators of human resources in science and technology. The other cause is that in a group of EU28 countries there are relatively very small countries (e.g. Cyprus, Malta) on one side and large countries like the United Kingdom, Germany and France on the other side. So the production function of R\&D is not straightforward.

Table 3. Spearman correlation coefficients among R\&D inputs and R\&D outputs

\begin{tabular}{lcc}
\hline Inputs / Outputs & High-tech exports & $\begin{array}{c}\text { Scientific } \\
\text { publications }\end{array}$ \\
\hline Expenditure in the government sector (GOVERD) & -0.069 & 0.218 \\
\hline Expenditure in the higher education sector (HERD) & 0.114 & $0.460^{* * *}$ \\
\hline Expenditure in the business sector (BERD) & 0.258 & $0.511^{* * *}$ \\
\hline Total researchers (FTE) & -0.045 & $0.978^{* * *}$ \\
\hline Human resources in science and technology (HRST) & $0.476^{* * *}$ & 0.203 \\
\hline Employment in total knowledge-intensive service sectors & $0.591^{* * *}$ & 0.235 \\
\hline
\end{tabular}

Notes: $* * *-\mathrm{p}<0.001$

Source: Authors calculation according Eurostat (2017) and SJR (2017) 
The number of indicators involved in DEA analysis was somewhat reduced due to non-significant associations among some indicators. If there is not at least formal significant association (e.g. correlation) between some input and output then there is no reason to involve them in DEA analysis. In our analysis further not use indicator R\&D expenditure in government sector as \% of GDP (GOVERD). All statistic reports were made in statistic software IBM SPSS version 19. Results of data envelopment analyses were obtained from DEA Solver Pro version 10.

\section{Results}

We use seven indicator in EU (28) in the year 2010 and 2015 (R\&D expenditure by higher education sector (HERD) and R\&D expenditure by business enterprise sector (BERD) (all as \% of GDP), total researchers (FTE), human resources in science and technology (HRST) \% of active population in the age group 25-64 and employment in total service intensive sectors as \% of total employment as inputs and as output indicators the number of scientific publications and high-tech export $\%$ of total export). Boxplots are useful exploratory graphs for a view of basic statistical characteristics (median, quartile range, skewness and outliers or extremes). Boxplots of all analysed indicators (besides GOVERD) are depicted in graphs $1-3$. We can see that indicators of R\&D expenditure, of human labour inputs and of high-tech exports have got skewed distributions in both periods. Outliers (circles) or even extremes (asterisks) are present in the case of researchers (FTE) and of scientific publications. Germany, the United Kingdom and France have got extremely large values of researchers (FTE) and of scientific publications.Outliers are not present in case of both expenditures (graph 1 and in case of human labour inputs and high-tech exports as output (graph 3). It neans that their distributions are rather homogenous.

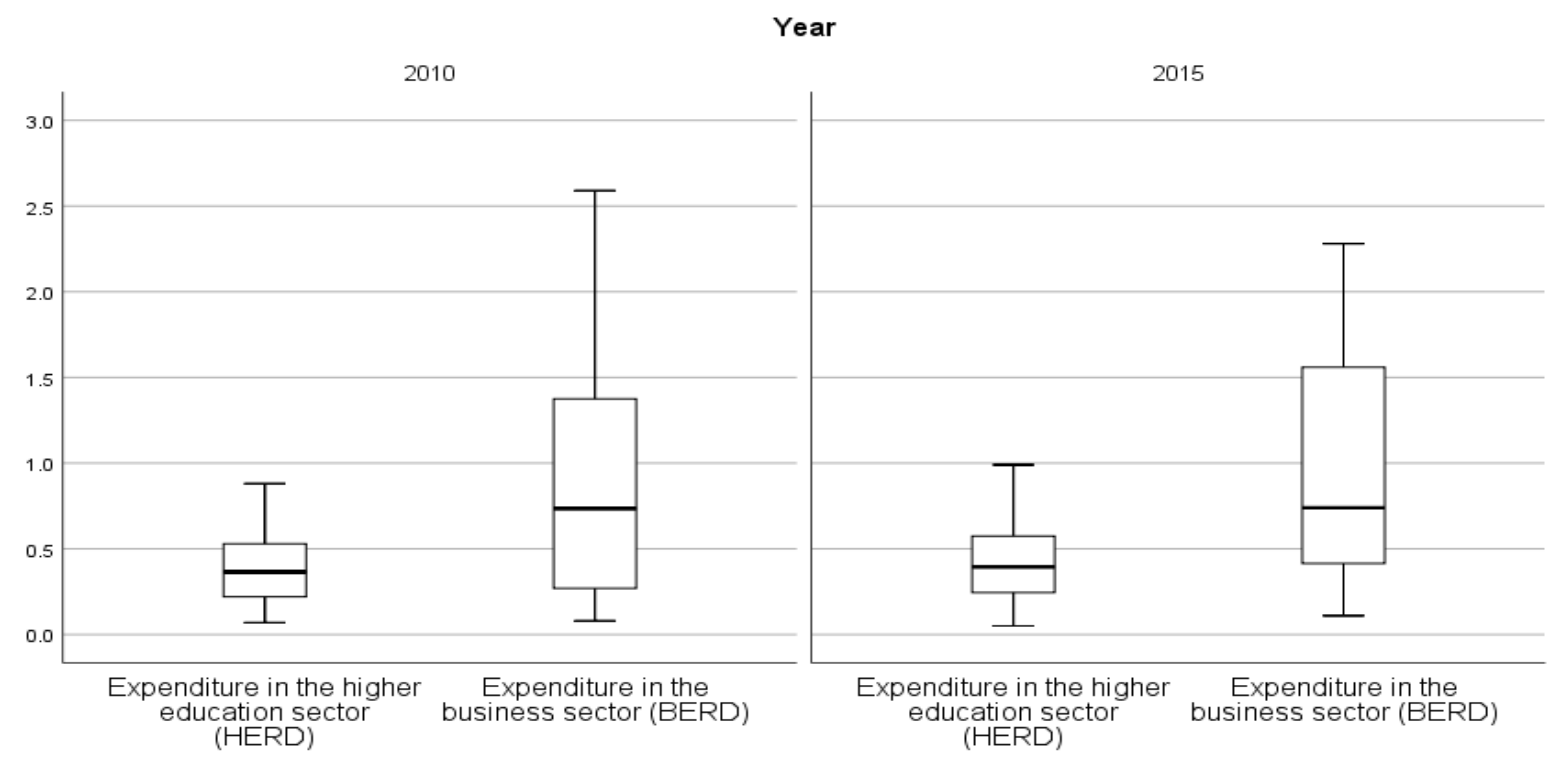

Graph 1. Boxplots of expenditure $R \& D$ in the higher education sector and in the business sector (both in \% of GDP) vs 2010 and 2015 in EU(28) countries

Source: Authors calculation according to Eurostat (2017) 


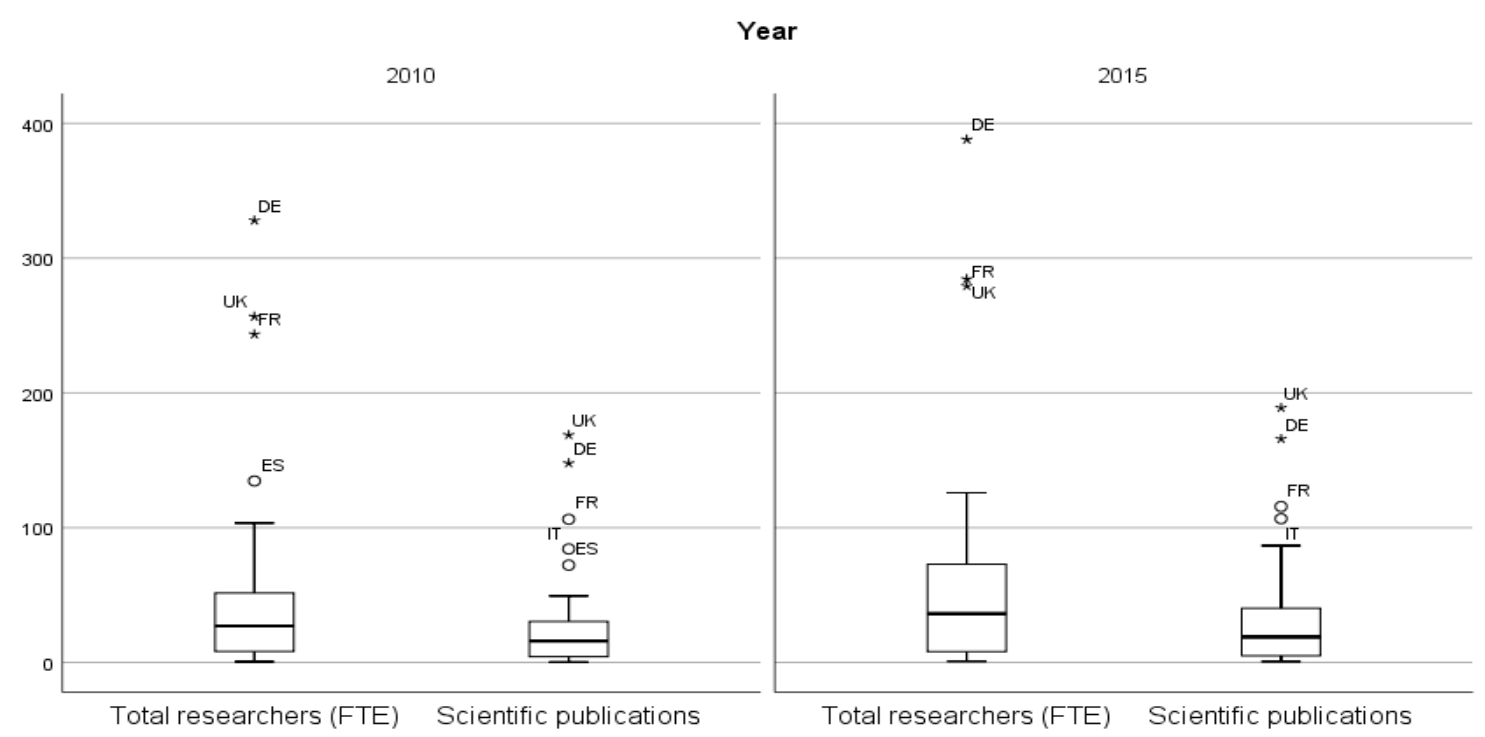

Graph 2. Boxplots of total researchers (FTE) and number of scientific publications (both in thousands) vs 2010 and 2015 in EU (28) countries

Source: Authors calculation according to Eurostat (2017) and SJR (2017)

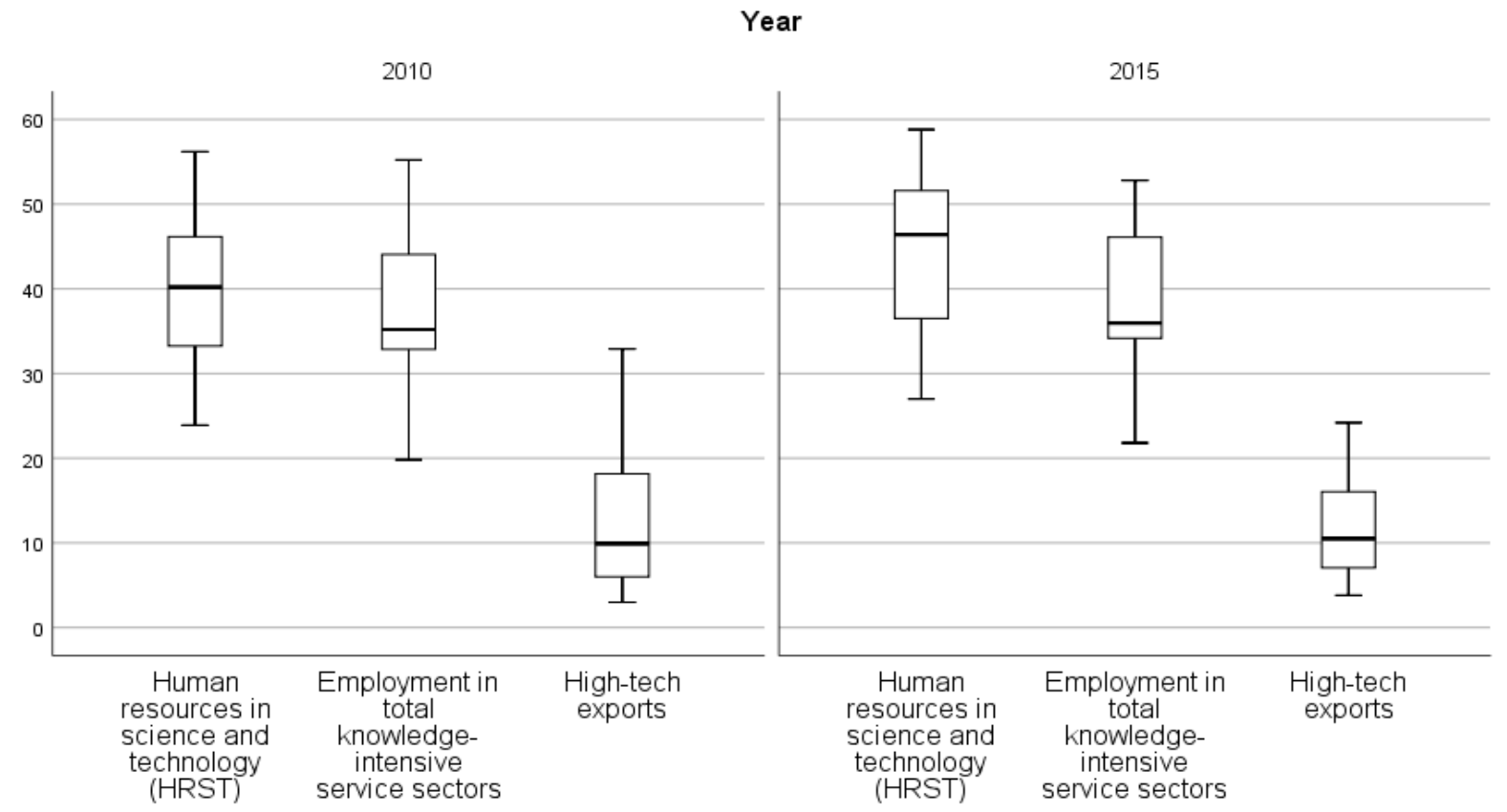

Graph 3. Boxplots of human labour inputs and high-tech exports as output (all as \%) vs 2010 and 2015 in EU (28) countries

Source: Authors calculation according to Eurostat (2017)

For analysis and evaluation of R\&D efficiency change in EU28 countries between 2010 and 2015 we use five input indicators - R\&D expenditure in the higher education sector and in the business enterprise sector (both as \% of GDP), total researchers (FTE), human resources in science and technology (HRST) \% of active population and employment in total service intensive sectors ( $\%$ of total employment) and two output indicators (the number of scientific publications and high-tech export $\%$ of total export). In Table 4 are final results of non-radial and non-oriented Malmquist index analysis of EU28 countries represented by 
available R\&D indicators. EU28 countries are sorted according to the Malmquist index in descending order.

Table 4. Malmquist index analysis of EU (28) countries R\&D indicators by non-radial and non-oriented model

\begin{tabular}{|c|c|c|c|c|c|}
\hline Rank & Country & Abbr. & Efficiency & Frontier & Malmquist \\
\hline 1 & Spain & ES & 1.564 & 0.892 & 1.395 \\
\hline 2 & Latvia & LV & 4.181 & 0.331 & 1.385 \\
\hline 3 & Denmark & DK & 1.572 & 0.760 & 1.194 \\
\hline 4 & Ireland & IE & 1.756 & 0.680 & 1.194 \\
\hline 5 & Slovakia & SK & 1.347 & 0.884 & 1.191 \\
\hline 6 & Slovenia & SI & 1.561 & 0.756 & 1.180 \\
\hline 7 & Italy & IT & 1.048 & 1.089 & 1.140 \\
\hline 8 & Lithuania & LT & 1.192 & 0.940 & 1.121 \\
\hline 9 & Belgium & $\mathrm{BE}$ & 1.473 & 0.758 & 1.116 \\
\hline 10 & Austria & AT & 1.300 & 0.820 & 1.065 \\
\hline 11 & Germany & $\mathrm{DE}$ & 1.017 & 1.041 & 1.058 \\
\hline 12 & Romania & RO & 1.157 & 0.903 & 1.045 \\
\hline 13 & France & FR & 1.393 & 0.730 & 1.017 \\
\hline 14 & United Kingdom & UK & 0.989 & 1.020 & 1.009 \\
\hline 15 & Croatia & $\mathrm{HR}$ & 0.995 & 1.007 & 1.002 \\
\hline 16 & Cyprus & $\mathrm{CY}$ & 0.948 & 1.034 & 0.981 \\
\hline 17 & Bulgaria & BG & 0.960 & 1.001 & 0.961 \\
\hline 18 & Czech Republic & $\mathrm{CZ}$ & 1.595 & 0.601 & 0.959 \\
\hline 19 & Sweden & SE & 1.183 & 0.790 & 0.934 \\
\hline 20 & Estonia & $\mathrm{EE}$ & 1.426 & 0.596 & 0.851 \\
\hline 21 & Finland & FI & 1.103 & 0.768 & 0.847 \\
\hline 22 & Netherlands & NL & 0.970 & 0.807 & 0.783 \\
\hline 23 & Hungary & $\mathrm{HU}$ & 1.172 & 0.653 & 0.765 \\
\hline 24 & Greece & EL & 0.907 & 0.772 & 0.700 \\
\hline 25 & Malta & MT & 0.797 & 0.770 & 0.614 \\
\hline 26 & Poland & $\mathrm{PL}$ & 0.615 & 0.886 & 0.545 \\
\hline 27 & Luxembourg & LU & 0.549 & 0.924 & 0.507 \\
\hline 28 & Portugal & PT & 0.292 & 0.827 & 0.242 \\
\hline
\end{tabular}

Source: Authors calculation

At first sight, we can say that the relatively best country from 28EU countries is Spain, followed by Latvia and by Denmark etc. But beware as indices (terms) in non-radial and nonoriented model Malmquist analysis can not be interpreted by common economic approach e.g. value of index equal to 1.2 does not mean a $20 \%$ increase. But it does mean increase or progression. Nevertheless, we can say that Spain is relatively better in comparison with Latvia, Denmark etc. from the viewpoint of Malmquist index analysis but not how much it is better. So we can use the rank of indices as a measure of the efficiency of EU28 countries. All $28 \mathrm{EU}$ countries from the viewpoint of R\&D indicators can be divided into six groups by term values (value $>1$ indicates progress, value $<1$ indicates regress). Relatively best group of countries with progress in both efficiency shift and frontier shift terms (Malmquist index $>1$ ) is represented by two countries Italy and Germany. The second group contains eleven countries with progress in efficiency shift term but with regress in frontier shift term (Malmquist index > 1): Spain, Latvia, Denmark, Ireland, Slovakia, Slovenia, Lithuania, Belgium, Austria, Romania and France. In the third group there are two countries with regress in efficiency shift term but with progress in the frontier term (Malmquist index > 1): the United Kingdom and Croatia. 
Last three groups contain five countries with regress in Malmquist total productivity index. In the fourth group are five countries with progress in efficiency shift term but with regress in the frontier term (Malmquist index < 1): Czech Republic, Sweden, Estonia, Finland and Hungary. The fifth group contains two countries with regress inefficiency term and with progress in the frontier term (Malmquist index < 1) - Cyprus and Bulgaria. The last sixth group is represented by the six relatively worst countries with regress in all three terms (efficiency shift, frontier shift and Malmquist index < 1): Netherlands, Greece, Malta, Poland, Luxembourg and Portugal. We consider the results for countries like Sweden, Finland and Netherlands with an overall decrease (Malmquist index $<1$ ) in R\&D efficiency as surprising ones because these countries are generally regarded as highly- developed countries. But we must keep in mind the following reasoning. Let us say that some kind of productivity in country A increased from 0.1 to 0.2 while in country B the same productivity decreased from 0.5 to 0.4 . Which country is better? If we consider only the fact of productivity change kind, then country A is better. We must be careful in such conclusions. It is better to say that developed countries are in nearly optimal state and for them, it is difficult to improve further their efficiencies while transition countries (like Slovakia) have got enough potential possibilities for improvement. It is on their heads. We can also compare all three terms according to a group of the country - capitalist country vs post-socialist country. Nonparametric Wilcoxon test is not significant (Efficiency change - $p=0.285$, Frontier change $-\mathrm{p}=0.404$ and Malmquist index $-\mathrm{p}=0.746$; boxplots in graph 4 overlap).

\section{Group}

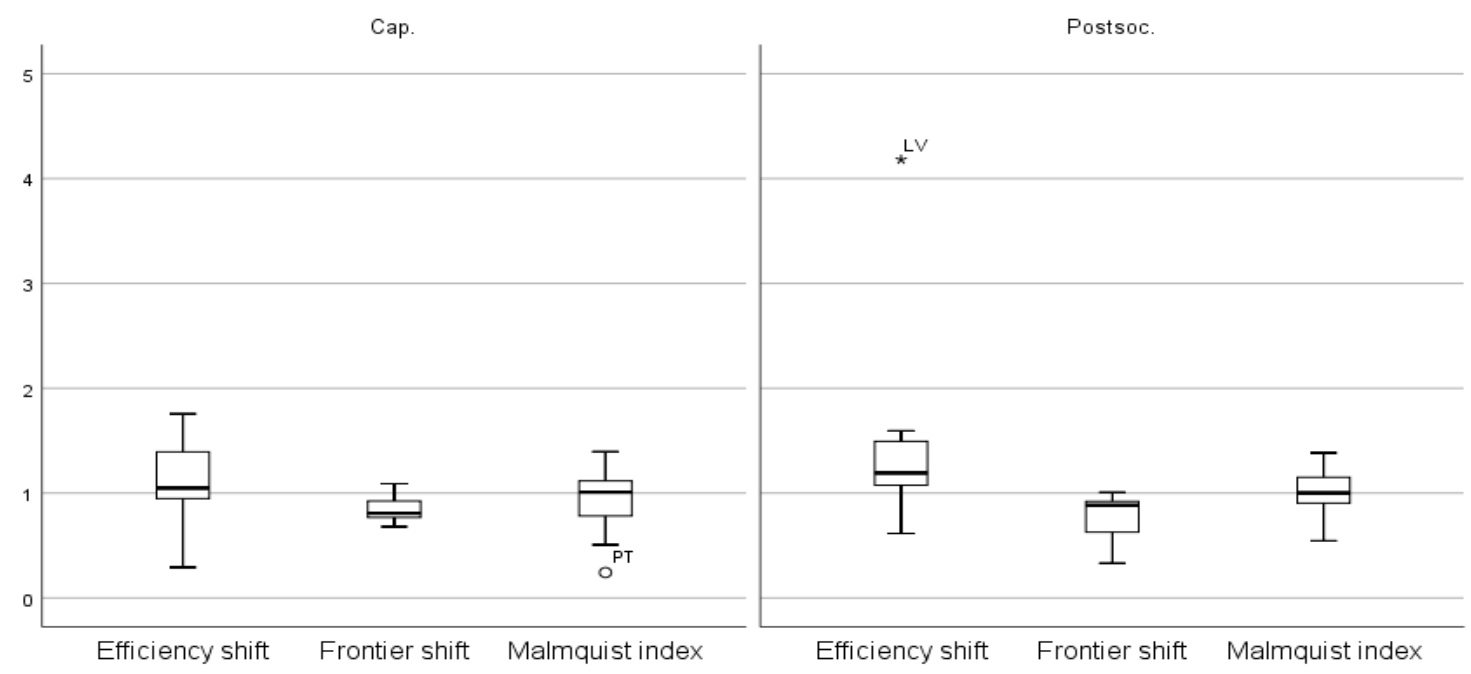

Graph 4. Boxplots of efficiency shift, frontier shift and Malmquist index by country group Source: Authors calculation

Relative positions of EU28 countries from the viewpoint of two Malmquist index terms are depicted in Graph 5. Besides EU28 countries is also depicted identity function. The countries above (below) the identity function line have got larger (smaller) frontier shift values in comparison with efficiency shift values. We can see that almost all EU28 countries are concentrated around point $(1.0,1.0)$ with the exception of one outlying cluster formed by Latvia in the right side of efficiency shift axis. In scatterplot, we can see relative positions of countries in two-dimensional space of efficiency change and of frontier change. Some of them almost overlap like Denmark and Slovenia while the others are far apart as the Czech Republic and Luxembourg. In our case, the larger (smaller) the value of an index term is, the better (worse) the case. So we consider a group of the largest (smallest) values as positive (negative) outliers or extremes. 


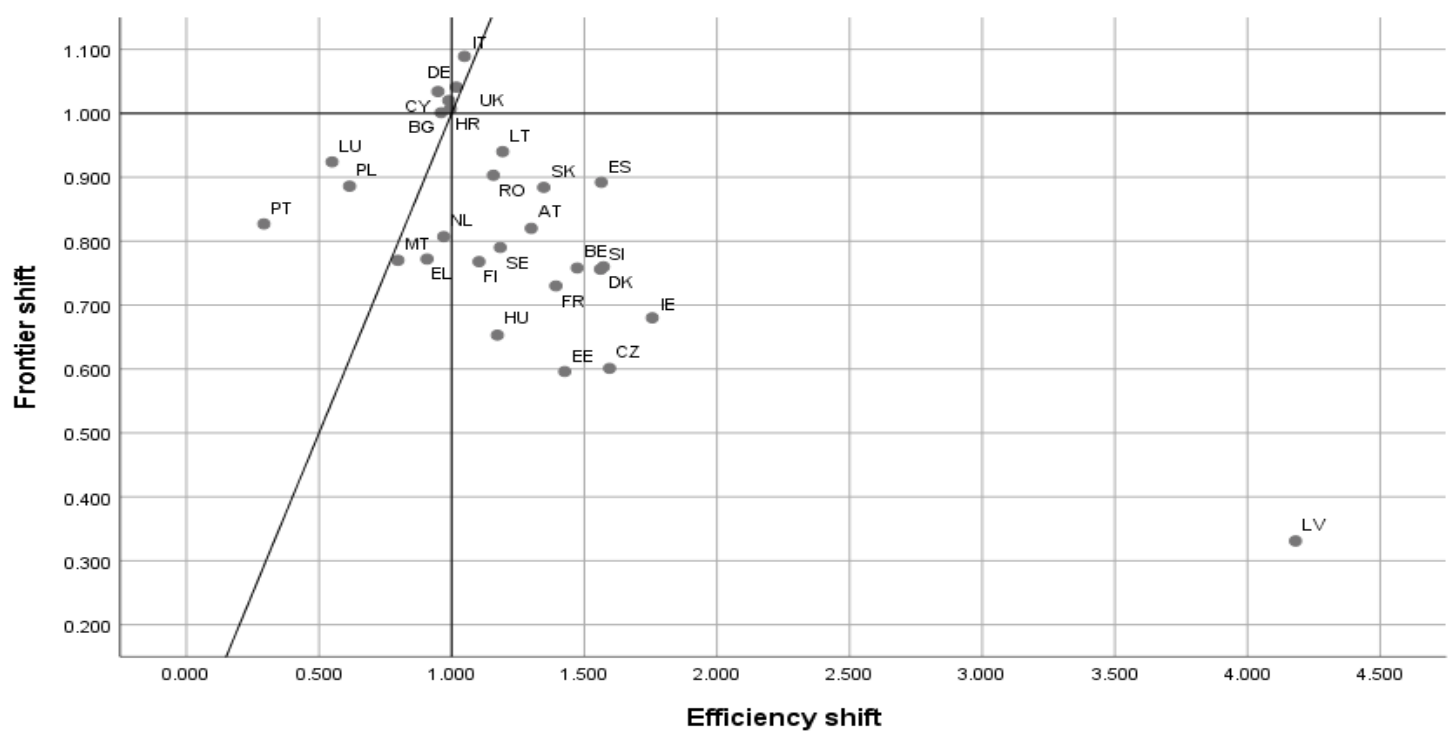

Graph 5. Scatter plot of frontier shift values vs efficiency shift values in EU countries Source: Authors calculation

In graph6 are boxplots of all three index terms. In efficiency shift, the positive extreme is seen in Latvia. But in frontier shift term same Latvia is a negative outlier. Malmquist index has got one negative outlier - Portugal.

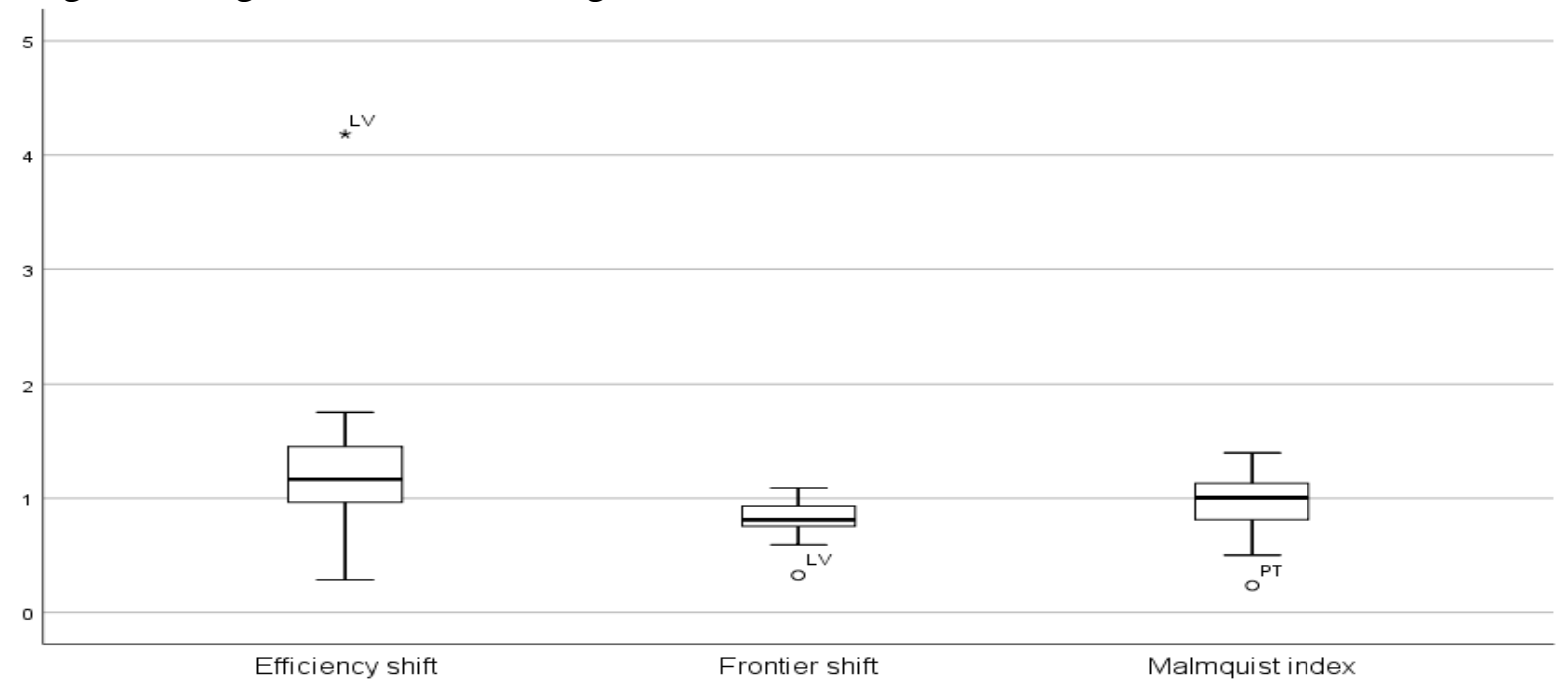

Graph 6. Boxplots of efficiency shift, frontier shift and Malmquist index by country Source: Authors calculation

In our case, we have got five inputs and two outputs of $\mathrm{R} \& \mathrm{D}$ indicators. It means optimization research problem is set in seven-dimensional space. Also, the cause of the state of results is located in this space.

\section{Discussion}

Evaluation and measurement of R\&D efficiency, productivity by used Data Envelopment Analysis and Malmquist index are addressed in the publications of many authors e.g. Dai and Liu (2009); Thomas, Jain and Sharma (2009); Lu and Liu (2010); Park (2015); Jang, Lee and Suh (2016); Han, Asmild and Kunc (2016); Guan et al. (2016); 
Karadayi and Ekinci (2019) or Li and Wang (2017). Our results of R\&D efficiency, using the Malmquist index, showed that 15 out of the $28 \mathrm{EU}$ countries evaluated, manifest an increase in R\&D efficiency between the years 2010 and 2015, with the highest shift in R\&D efficiency in Italy and Germany. In nine countries, a prevalent financial potential in the business enterprise sector was found. By contrast, in four countries with a small on no shift in $R \& D$ efficiency between the years 2010 and 2015 was a predominant financial potential in the government sector was proved. As a result, the first research question was proved, namely that a higher R\&D efficiency is associated with a prevalent financial potential in the business enterprise sector. When evaluating the shift of R\&D efficiency between the years 2010 and 2015 in post-socialist countries compared to the countries of the former EU (15), it can be said that not all post-socialist countries saw a low R\&D efficiency. A low R\&D efficiency was not proved in Latvia, Slovakia, Slovenia, Lithuania or Romania. On the contrary, six countries of the former EU (15) show almost no changes in R\&D efficiency. Based on the results, it can be said that the second research question was proved only partially.

Also, the results of other studies e.g. Park (2015) show the efficiency and productivity change within government subsidy recipients of a national technology innovation research and development (R\&D) program during the entire period analyzed (2010-2012). Jang, Lee and Suh (2016) measure the cumulative change in research and development (R\&D) efficiency of globally leading $R \& D$ companies in the technology industry and their results indicate that the overall $R \& D$ efficiency of these globally leading $R \& D$ companies declined slightly during the period 2007-2013. Results of the research by Li and Wang (2017) proved that major problems of low efficiency of input-output performance of R\&D activities of the major sectors of industrial enterprises are determined as the imbalance of R\&D investment among industries, the unreasonable structure of input and output, the inefficient use of resources, and the weak transformation ability of achievements in scientific research. Other results $\mathrm{Lu}$ and Liu (2010) indicate that the increase in R\&D productivity is mainly attributed to the increase in technical change, and the efficiency gain found is largely the result of improvements in scale efficiency.

According to many authors and studies (Albu, 2011, Becker, 2015; European Commission, 2016) these differences can be explained by different national R\&D policies, including their priorities, but also the position of the public and business-enterprise sector with respect to the Europe 2020 strategy. Differences in the evaluation of R\&D policy indicators are also associated with varying intensity of content-related priorities in research and development since every single country creates its own concept of national policy in R\&D (in 4-6 year perspective). Also, initial conditions and potential of the given state in terms of the development of science and research and innovation-related policy, requirement of the European research area (ERA) or the target connected with the fulfilment of the Europe 2020 strategy in R\&D financing (fulfilled for a long time by some countries) need to be considered as well. Other causes of the varying position of countries are then connected with the structure and extent of research and science and innovation potential and the possibilities of its exploitation.

\section{Conclusion}

The objective of the paper was the analysis and evaluation of R\&D efficiency change in EU28 countries between 2010 and 2015. In the paper the authors used non-radial and nonoriented Malmquist index DEA model of available R\&D indicators of EU28 countries. We have found six groups of EU28 countries from the viewpoint of three index terms values (efficiency shift, frontier shift and Malmquist index). Relatively best group of countries with 
progress in both efficiency shift and frontier shift terms (Malmquist index $>1$ ) is represented by two countries Italy and Germany. The second group contains eleven countries with progress in efficiency shift term but with regress in frontier shift term (Malmquist index > 1): Spain, Latvia, Denmark, Ireland, Slovakia, Slovenia, Lithuania, Belgium, Austria, Romania and France. In the third group there are two countries with regress in efficiency shift term but with progress in the frontier term (Malmquist index $>1$ ): the United Kingdom and Croatia. Last three groups contain five countries with regress in Malmquist total productivity index. In the fourth group are five countries with progress in efficiency shift term but with regress in the frontier term (Malmquist index < 1): Czech Republic, Sweden, Estonia, Finland and Hungary. The fifth group contains two countries with regress in efficiency term and with progress in the frontier term (Malmquist index < 1) - Cyprus and Bulgaria. The last sixth group is represented by six relatively the worst countries with regress in all three terms (efficiency shift, frontier shift and Malmquist index $<1$ ): Netherlands, Greece, Malta, Poland, Luxembourg and Portugal. We have found by a nonparametric test that post-socialist countries are not different from capitalist EU countries from the viewpoint of efficiency change between 2010 and 2015. An important role in most countries is the fulfilment of the Europe 2020 strategy in terms of R\&D funding but also improvement of other indicators related to the assessment of innovation performance, increasing the competitiveness of the economies and creating new jobs. Evaluation efficiency $R \& D$, productivity and innovative performance are very important for many European but also other countries and this area can be a theme for further research.

\section{Acknowledgement}

This paper was created within the project Operational Programme Education for Competitiveness (Project No. CZ. 1.07/2.3.00/20.0296).

This work is supported by the Scientific Grant Agency of the Ministry of Education, Science, Research, and Sport of the Slovak Republic and the Slovak Academy Sciences as part of the research project VEGA 1/0843/18: Methodological aspects of DEA application on efficiency assessment of production units.

\section{References}

Albu, N. (2011). Research and development spending in the EU: 2020 growth strategy in perspective. WP, 8, 2011.

Becker, B. (2015). Public R\&D policies and private R\&D investment: A survey of the empirical evidence. Journal of Economic Surveys, 29(5), 917-942. https://doi.org/10.1111/joes.12074.

Bilan, Y., Mishchuk, H., Samoliuk, N., \& Grishnova, O. (2019). Ict And Economic Growth: Links And Possibilities Of Engaging. Intellectual Economics, 13(1), 93-104. https://doi.org/10.13165/IE-19-13-1-07

Braczyk, H. J., Cooke, P., \& Heidenreich, M. (2004). Regional innovation systems the role of governance in a globalized world. New York: Routledge. https://doi.org/10.4324/9780203330234

Borrás, S., \& Edquist, C. (2013). The choice of innovation policy instruments. Technological $\begin{array}{llll}\text { forecasting } \text { and social change, } & \text { 150(8), }\end{array}$ https://doi.org/10.1016/j.techfore.2013.03.002

Bojnec, Ś., \& Ferto, I. (2014). Research and development spending and export performance by the technological intensity of the products. Ekonomický časopis, 62(10), 1065-1080. 
Cooper, W. W., Seiford, L. M., \& Tone, K. (2007). Data Envelopment Analysis. A comprehensive text with models, applications, references and DEA-solver software. New York: Springer. doi: 10.1007/978-0-387-45283-8.

Corea, P. (2014). Public expenditure reviews in science, technology, and innovation. A guidance note. Washington: World Bank Group. <https://openknowledge.worldbank.org/handle/10986/21064>

Cowan, R., \& Van De Paal, G. (2000). Innovation policy in a knowledge-based economy.

Brussels-Luxembourg: Commission of the European Communities. [Publication no. EUR 17023 of the Commission of the European Communities].

Dai, F., \& Liu, G. (2009). R\&D efficiency and productivity growth: A Malmquist index analysis of High-Tech industries in China. In: International Conference on Management Science and Engineering. [Proceedings.] pp. 1866-1872. https://doi.org/10.1109/icmse.2009.5317726.

Dobrzanski, P. (2018). Innovation expenditures efficiency in Central and Eastern European Countries. Zbornik radova Ekonomskog fakulteta u Rijeci: časopis za ekonomsku teoriju i praksu, 36(2), 827-859. doi: 10.18045/zbefri.2018.2.827.

Drastichová, M. (2015). Sustainability Evaluation of the European Union. In Proceedings of the 9th International Scientific Conference INPROFORUM „Common challenges Different solutions - Mutual dialogue, pp. 31-39.

Dvorský, J., Petráková, Z., Çera, G., \& Folvarčná, A. (2019). Important factors for the entrepreneurship in Central Europe. Marketing, 15(2), 71-83. doi:10.21511/im.15(2).2019.06

Dul'ová Spišáková, E., Mura, L., Gontkovičová, B., \& Hajduová, Z. (2017). R\&D in the context of Europe 2020 in selected countries. Economic Computation and Economic Cybernetics Studies and Research, 51(4), 243-261.

European Commission. (2016). Science, research and innovation performance of the EU. Brussels: European Commission. ISBN 978-92-79-49557-1.

European Commission. (2018). European research area (ERA). http://ec.europa.eu/research/era/index_en.htm.

Ekinci, Y., \& Karadayi, M. L. (2017). Analysis of the research and development efficiencies of European Union countries. Business \& Management Studies: An International Journal, 5(1), 1-19.

Eurostat (2017). Statistics database - Research, science and development. http://ec.europa.eu/eurostat/data/database.

Freeman, C. (1995). The national innovation systems in historical perspective. Cambridge Journal of Economics, 19(1), 5-24.

Fried, H.O., Knox Lovell, C. A., \& Schmidt, S. S. (2008). The measurement of productive efficiency and productivity growth. Oxford: Oxford University Press.

Guan, JC., Zuo, KR., Chen, KH., \& Yam, RCM. (2016). Does country-level R\&D efficiency benefit from the collaboration network structure?. Research Policy, 45(4), 770-784. https://doi.org/10.1016/j.respol.2016.01.003.

Hackett, E. J., Amsterdamska, O., Lynch, M., \& Wajcman, J. (2008). The handbook of science and technology studies. London: Cambridge, the MIT Press.

Halaskova, M., \& Bazsova, B. (2016). Evaluation of the efficiency of research and development in EU countries. Acta academicakarviniensia, 16(4), 32-45. https://doi.org/10.25142/aak.2016.030.

Han, U., Asmild, M., \& Kunc, M. (2016). Regional R\&D efficiency in Korea from static and dynamic perspectives. Regional Studies, 50(7), 1170-1184. https://doi.org/10.1080/00343404.2014.984670. 
Hawdon, D. (2003). Efficiency, performance and regulation of the international gas industry a bootstrap DEA approach. Energy Policy, 31(11), 1167-1178. https://doi.org/10.1016/s0301-4215(02)00218-5.

Hei Cheung, J., Sung Hur, K., \& Jong Park, S. (2019). Are capitalized R\&D and expensed $\mathrm{R} \& \mathrm{D}$ costs "sticky"? Korean evidence. Investment Management and Financial Innovations, 16(2), 89-100. doi:10.21511/imfi.16(2).2019.08

Ivanová, E., \& Čepel, M. (2018). The Impact of Innovation Performance on the Competitiveness of the Visegrad 4 Conutries. Journal of Competitiveness, 10(1), 54-72. https://doi.org/10.7441/joc.2018.01.04.

Jang, H., Lee, S., \& Suh E. (2016). A comparative analysis of the change in R\&D efficiency: A case of R\&D leaders in the technology industry. Journal Technology Analysis \& $\begin{array}{lll}\text { Strategic } \quad \text { Management, } & \text { 886-900. }\end{array}$ https://doi.org/10.1080/09537325.2016.1180354.

Jaumotte, F., \& Pain, N. (2005). From ideas to development: The determinants of $R \& D$ and patenting. OECD: OECD Economics Department [Working Paper No. 457].

Karadayi, MA., \& Ekinci, Y. (2019). Evaluating R\&D performance of EU countries using categorical DEA. Technology Analysis \& Strategic Management, 31(2), 277238.https://doi.org/10.1080/09537325.2018.1493191.

Kiselakova, D., Sofrankova, B., Cabinova, V., Onuferova, E., \& Soltesova, J. (2018). The Impact of R\&D Expenditure on the Development of Global Competitiveness within the CEE EU Countries. Journal of Competitiveness, 10(3), 34-50. https://doi.org/10.7441/joc.2018.03.03.

Laliene, R., \& Sakalas, A. (2014). Conceptual Structure of R\&D Productivity Assessment in Public Research Organizations.Economics and Management, 19(1/2014), 25-34. https://doi.org/10.5755/j01.em.19.1.5755.

Lee, H. Y, \& Park, Y. T. (2005). An international comparison of R\&D efficiency: DEA Approach. Asian J. Technology Innovation, 13(2), 207-222. https://doi.org/10.1080/19761597.2005.9668614.

Li, R., Wang, S. (2017). Evaluation and analysis on R\&D input-output performance of the major sectors of industrial enterprises based on the DEA method. Revista de la Facultad de Ingenieria, 32 (1), 430-445.

Lu, W.CH., \& Liu, T.K. (2010). Malmquist indices of R\&D productivity growth in taiwanese ic-design industry. Global journal of business research, 4(1).

Machová, R., Mura, L., Havierniková, K., \& Tóth, Zs. (2017). The entrepreneur's network as a cooperation form of entrepreneurship: Case of Slovakia. Journal of Applied Economic Sciences, 12(1), 160-169.

Melecky, L., \& Stanickova, M. (2012). National Efficiency Evaluation of Visegrad Countries in Comparison with Austria and Germany by Selected DEA Models. In: International Conference on Mathematical Methods in Economics. [Proceedings.] Karvina: Silesian University Opava, Faculty of School Business Administration, pp. 575-580.

Mishchuk, H., \& Grishnova, O. (2015). Empirical study of the comfort of living and working environment - Ukraine and Europe: comparative assessment. Journal of International Studies, 8(1), $67-80$.

Mishchuk, H., Roshchyk, I. Sułkowska, J., \& Vojtovič, S. (2019). Prospects of Assessing the Impact of External Student Migration on Restoring the Country's Intellectual Potential (Case Study of Ukraine). Economics \& Sociology, 12(3), 209-219. doi:10.14254/2071789X.2019/12-3/14

Moed, H.F., Glänzel, W., \& Schmoch, U. (2005). Handbook of quantitative science and technology research- the use of publication and patent. statistics in studies of $S \& T$ 
systems. New York, Boston, Dordrecht, London, Moscow: Kluwer Academic Publishers. ISBN 1-4020-2755-9.

Nasierowski, W., \& Arcelus, F. J. (2012): About efficiency of innovations: What can be learned from the innovation union scoreboard index. Procedia - Social and Behavioral Sciences, 58, 792-801. https://doi.org/10.1016/j.sbspro.2012.09.1057

Park, S. (2015). Evaluating the efficiency and productivity change within government subsidy recipients of a national technology innovation research and development program. $R \& D$ Management, 45(5), 549-568.https://doi.org/10.1111/radm.12097

Prokop, V., \& Stejskal, J. (2017). Different approaches to managing innovation activities: An analysis of strong, moderate, and modest innovators. Inzinerine Ekonomika Engineering Economics, 28(1), 47-55.

Prokop, J., \& Karbowski, A. (2018). R\&D spillovers and cartelization of industries with differentiated products. Journal of International Studies, 11(3), 44-56. doi:10.14254/2071-8330.2018/11-3/4

Ravselj, D., \& Aristovnik, A. (2018). The impact of private research and development expenditures and tax incentives on sustainable corporate growth in selected OECD countries. Sustainability, 10 (7), 1-16. doi: 10.3390/su10072304.

Ŕíhová, L., Písař, P., \& Havlíček, K. (2019). Innovation potential of cross-generational creative teams in the EU. Problems and Perspectives in Management, 17(4), 38-51. doi:10.21511/ppm.17(4).2019.04

Rodríguez-Pose, A., \& Crescenzi, R. (2008): Research and development, spillovers, innovation systems, and the genesis of regional growth in Europe. Regional Studies, 42(1), 51-67. https://doi.org/10.1080/00343400701654186

Sachs, L. (1984). Applied statistics. A handbook of techniques. New York: Springer.

Sharma, S., \& Thomas, V. (2008). Inter-country R\&D efficiency analysis: An application of data envelopment analysis. Scientometrics, 76(3), 483-501. https://doi.org/10.1007/s11192-007-1896-4

Sherman, H. D., \& Zhu, J. (2006). Service productivity management: Improving service performance using data envelopment analysis (DEA). New York: Springer.

SJR (2017). Scimago Journal \& Country Rank. http://www.scimagojr.com/countryrank.php.

Staníčková, M. (2017). Can the implementation of the Europe 2020 Strategy goals be efficient? The challenge for achieving social equality in the European Union. Equilibrium-Quarterly Journal of Economics and Economic Policy, 12(3), 383-398. https://doi.org/10.24136/eq.v12i3.20.

Stepanova, A., Bediukh, O., Novikova, I. (2019). Contradictions of enterprise Europe network development in Ukraine. Problems and Perspectives in Management, 17(4), 190-202. doi:10.21511/ppm.17(4).2019.16

Szarowska, I. (2017): Does public R\&D expenditure matter for economic growth? GMM approach. Journal of International Studies, 10(2), 90-103. https://doi.org/10.14254/2071-8330.2017/10-2/6.

Thomas, V. J., Jain, S. K., \& Sharma, S. (2009). Analyzing $R \& D$ Efficiency in Asia and the OECD: An Application of the Malmquist Productivity Index. <https://smartech.gatech.edu/bitstream/handle/1853/32338/317-658-1-PB.pdf>.

Tone, K. (2002). A Slacks-based measure of super-efficiency in data envelopment analysis. European Journal of Operational Research, 143(1), 32-41.

Van Raan, A. F.J., Van Leeuwen, T.N., \& Calero-Medina, C. (2009). Performance of European science: research networks and profiles of EU countries in a global perspective. In: Delanghe, H., Muldur, U., Soete, L. (eds). European Science and 
Technology Policy. Towards Integration or Fragmentation. Cheltenham, Northampton, MA: Edward Elgar Publishing, pp. 256-290.

Wang, E. C., \& Huang, W. (2007). Relative efficiency of R\&D Activities: A cross-country study accounting for environmental factors in the DEA approach. Research Policy, 6(2), 260-273. https://doi.org/10.1016/j.respol.2006.11.004.

Žítek, V., Klímová, V., \& Králová, M. (2016). Assessment of Regional Innovation Systems as an Assumption for Innovation Policy Adjustment. Transylvanian Review of Administrative Sciences, (49, E/2016), 169-186. 